\title{
EXPERIENCE
}

\section{Identity as a narrative of autobiography}

\author{
Luba Jakubowska \\ jm@wp.pl
}

\begin{abstract}
This article is a proposal of identity research through its process and narrative character. As a starting point I present a definition of identity understood as the whole life process of finding identification. Next I present my own model of auto/biography-narrative research inspired by hermeneutic and phenomenological traditions of thinking about experiencing reality. I treat auto/biography-narrative research as a means of exploratory conduct, based on the narrator's biography data, also considering the researcher's autobiographical thought. In the final part of the article I focus on showing the narrative structure of identity and autobiography. I emphasise this relation in definitions qualifying autobiography as written life narration and identity as a narration of autobiography.
\end{abstract}

Key words: narration, autobiography, identity, quality research, auto/biography-narrative research, hermeneutics, phenomenology.

\section{Definition of identity}

When dealing with identity a researcher may have problems differentiating between the numerous and often fundamentally distinct theories regarding the notion. The variety of models of identity has been demonstrated by, among others, R. Robbins. This author presents the identity health model, the identity interaction model, and the identity worldview model (Nikitorowicz 2001, p. 74). Closest to my understanding of the notion is the identity interaction model, since I perceive identity as a process. This conclusion is based not so much on symbolic interactionism, but as on the idea of human lifelong development. On the basis of that theory the idea of lifelong learning has been constructed. The theory deals with the lifelong learning and (self)education of an individual. An individual learns and is being 
"formed" throughout his entire life, therefore, one's system of values may be changed at any time - the ideals, opinions, etc., may be changed permanently. Based on the idea of lifelong development, as presented, among others, by E. Sujak (Sujak 1998, p. 30-31), and the biographical approach to identity, as presented by A. Giddens (Giddens 2002, p. 318), identity is to be defined as: the constant process of one's searching for a point of reference through accepting and altering certain identifications while rejecting others. Accepted identifications are transformed, since their importance, as perceived by an individual, changes with time. Ideas, norms, opinions, values, etc., constitute the identifications that are/were accepted by individuals (authorities) as well as groups.

To complement the definition it must be stated that all identifications, including rejected ones, are relevant to the understanding of identity.

\section{Auto/biographical-narrative research. Research model}

When considering the methods of research sufficient for the investigation of identity understood as a constant process, a question arises as to the relation of the problem to philosophical paradigms. I believe that the understanding of methodology should not be limited to research methods and techniques. In my opinion, the epistemological and ontological aspects of the methods used are of crucial importance. Reaching the sources is fundamental in planning and conducting research.

In my research so far I have used mostly qualitative methods, as these are in accordance with my interpretation of reality. However, it is not the researcher's preferences that are decisive in the choosing of methods - it is the subject of the research.

Qualitative research methods are present in three paradigms ${ }^{1}$ : interpretive, critical and postmodernist. Narrative-biographical research is based on the interpretive paradigm. Methodology of the postmodernist paradigm is used as well. That is because among the four research paradigms ${ }^{2}$ the postmodernist one puts the most emphasis on the role of the researcher in empirical research.

In conclusion, the model of research of identity understood as a process has been constructed on the basis of triangulation of methods as employed in qualitative research (see

\footnotetext{
${ }^{1}$ According to T.S. Kuhn, a paradigm is to be defined as: generally accepted scientific achievements that during a certain period of time provide scholars with models of problems and solutions (Kuhn 1968, p. 12).

${ }^{2}$ Positivist, interpretive, critical, postmodernist.
} 
fig. 1). In this model, the narrative-biographical method of the interpretive paradigm $^{3}$ and the auto/biographical method (Miller 2003) and the trajectory of researcher's "self" (Usher, Bryant, Johnston 2001) of the postmodernist approach have been combined.

\begin{tabular}{|l|l|}
\hline \multirow{2}{*}{ Postmodernist approach } & Interpretive paradigm \\
\cline { 2 - 2 } & $\begin{array}{l}\text { Hermeneutics } \\
\text { Phenomenology }\end{array}$ \\
\hline Narrative-auto/biographical research \\
\hline $\begin{array}{l}\text { Auto/biographical research } \\
\text { Trajectory of researcher's "self" }\end{array}$ & Biographical method \\
\hline
\end{tabular}

Fig. 1. Triangulation of methods; source: compiled by the author

Based on the triangulation of methods, the following research model has been constructed:

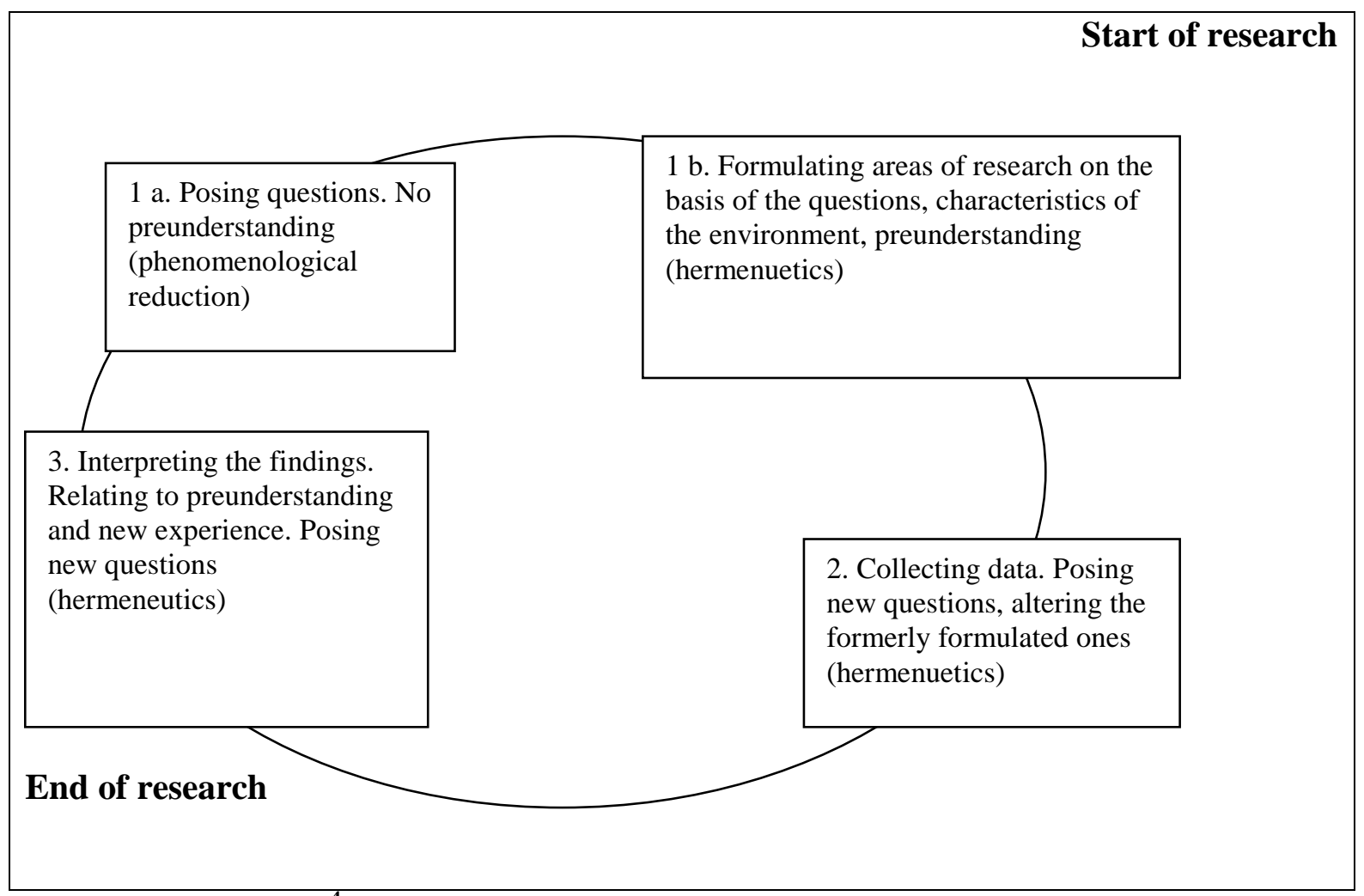

Fig. 2. Area of research ${ }^{4}$; source: compiled by the author

\footnotetext{
${ }^{3}$ Autobiographical-narrative research is present also in the critical paradigm; I will not, however, discuss that approach.

${ }^{4}$ The model of research constructed on the basis of phenomenological reduction located upon a hermeneutical cycle is to be found in the following works: A. Wyka (1993), Badacz spoteczny wobec doświadczenia, p. 58 and M. Pryszmont (2004), Eklektyzm metodologiczny, czyli interparadygmatyczne przygody badawcze; Phenomenological-hermeneutical research is also described in: K. Ablewicz (1998), Hermeneutyka $i$
} 
The term narrative-biographical in relation to research is employed according to D. Urbaniak-Zając. The term indicates that the source of data is the narrative and their subject of reference is biography (Urbaniak-Zając 2005, p. 116). As seen in the figure above, the prefix "auto" has been added to the term, which requires explanation. The aforementioned author states that if an author of a text gives an account of his/her own life, the outcome is an autobiography, in other cases it is a biography (Urbaniak-Zając 2005, p. 115-116). One cannot disagree. However, we must elaborate upon that differentiation in the methodological context.

In case of biographical narratives of research subjects, just as in all biographical stories, we encounter a number of characters. Regardless of that, only the narrator of the story is a subject of research. Therefore, the stories are to be rendered autobiographies. A question must be raised, however, whether through the recording and interpreting by a researcher the narrators' autobiographies become biographies. From this point of view, it is only the researcher's narrative that becomes an autobiography. That is why the safest term regarding this type of research has been proposed by N. Miller. That author discusses auto/biographical research. The term includes the autobiographies and biographies of research subjects as well as the autobiography of the researcher. The source of data in auto/biographical research are lifelong narratives of research subjects and the researcher (Miller 2003). Therefore, the method of research is to be called narrative-auto/biographical. The figure below illustrates the research method.

\begin{tabular}{|l}
$\begin{array}{l}\text { Researcher's } \\
\text { autobiography }\end{array}$ \\
$\begin{array}{l}\text { Referring to autobiographical } \\
\text { experience }\end{array}$ \\
trajectory of researcher's "self" \\
taking into account personal \\
influence of the researcher
\end{tabular}

fenomenologia w badaniach pedagogicznych and M. Nowak-Dziemianowicz (2006), Doświadczenia rodzinne w narracjach. 
on the research

Fig. 3. Narrative-auto/biographical research; source: compiled by the author

The figure above illustrates the relations between the researcher and the research subjects. When conducting an auto/biographical research the researcher has influence both on the research process and the research subjects by, for example, causing self-reflection by asking questions. The influence is reciprocal, because the narrators become a part of the researcher's biography.

\section{Philosophical and methodological basis of the auto/biographical-narrative research}

In the description of an autobiography, understood as a subjective interpretation of one's own life, a number of categories typical of traditional sociology appear: constructive character of subjectivity (intentionality), relating to values, life as a process of constant interpretation, understanding as the exclusive means of contact with cultural reality (Giza 1991, p. 99).

A basic category of autobiography is the understanding of interpretation as the interpretation that points towards the forerunners of the interpretive paradigm, the classics of all "understanding" trends (Krasnodębski 1986, p. 72) - Wilhelm Dilthey and Max Weber. The former heavily criticized the employing of natural scientific research methods in the world of culture to name hermeneutics the correct method in social sciences (Kozakiewicz 1991, p. 66). The Verstehen research procedure based on participatory examination (Krasnodębski 1986, p. 85) was to guarantee objectivism (Kozakiewicz 1991, p. 67-68). The ideas of W. Dilthey have been heavily criticized. Therefore, it was only with the help of M. Weber, the father of "understanding" sociology (Malewski 1998, p. 29), that the interpretive method gained wide acceptance. As opposed to his predecessor, instead of direct experience as means of understanding society $\mathrm{M}$. Weber proposed to complement understanding with rational explanation (Benton, Craib 2003, p. 75). Therefore, in place of the empathic Verstehen, as proposed by W. Dilthey, the fundamental method in sociology according to M. Weber was to be the "understanding explanation" or the "explaining understanding" (Benton, Craib 2003, p. 75). With the works of A. Schütz the category of understanding, as proposed by M. Weber, found its way to the phenomenological school of thought. According to that author the aim of interpretive sociology is the description of the acts of interpretation and constituting meaning, as performed by those functioning in a society, as well as the 
interpretation of meaning of all the products of those acts (Krasnodębski 1986, p. 114-115). All of the aforementioned authors attempted to make the interpretive method a method of objective cognition, based on experience - W. Dilthey (Kozakiewicz 1991, p. 68), rational explanation and observation - M. Weber) (Kozakiewicz 1991, p. 75), or objectivity of the researcher - A. Schütz (Krasnodębski 1986, p. 143). However, this particular category along with all the qualitative methods based on understanding as means of cognition of reality are still criticised for allegedly being "subjective" and "unscientific".

In this article I will not attempt to address the arguments against the qualitative research. It is my belief that the qualitative method needs no advocate, due to immense popularity of that type of research in contemporary social sciences. The opposition between the qualitative and quantitative method is no longer prevalent (Urbaniak-Zając 2001, p. 13). Many contemporary scholars propose to merge the two orientations (Malewski 1997). However, although I personally accept the combining of methods within the orientations (qualitative and quantitative), I am opposed to the combining of qualitative and quantitative methods in a single research.

The qualitative research that I am concerned with is a combination of two schools of the qualitative paradigm - phenomenology and hermeneutics. While recognizing the important differences between phenomenology and hermeneutics, I base my research upon the methodological and philosophical aspects of both schools of thought. That is justified, as I perceive neither phenomenology nor hermeneutics as means of scholarly investigation. They are the fundamental concepts forming the interpretive paradigm, which I understand as the root of auto/biographical-narrative research. The interpretive paradigm can be illustrated thus:

\begin{tabular}{|l|l|}
\hline Planes of methodology & Paradigm \\
\hline ontological & Society - inter-subjective, composed through constant interpretation \\
\hline epistemological & Dynamic knowledge, created by human mind \\
\hline methodical & Researcher as an observer or full participant \\
\hline
\end{tabular}

Fig. 4. Interpretive paradigm; source: Malewski 1997, Malewski 1998, author's compilation

Addressing the various contexts of methodology (ontological, epistemological, methodical), as proposed by M. Malewski, I shall describe the nature of qualitative research.

The subject of qualitative research is society. It is an inter-subjective world - full of meanings; the world of human culture. It is not an objective world of nature - it is created by 
individual human beings, conscious of their actions (Benton, Craib 2003, p. 92). The ontological assumptions connected with the subject of research influence the understanding of knowledge within the interpretive paradigm, which, in turn, is reflected in research procedure. In the humanist tradition (as opposed to the scientific character of the positivist paradigm) what is fundamental for a researcher is not the theory, but the social reality itself, as formed by people - actors on the scene of society (Malewski 1997, p. 18). According to M. Weber, human actions are sensible and rational (Benton, Craib 2003, p. 93). That is why it is the "mind of the researcher" that constitutes the means of cognition. Observation, as understood by empiricists, turns out to be insufficient in the study of the meanings of human actions. Rational thinking and empathy are more useful in the study of society than the senses. Although the beginning of qualitative research is to be the 1920's (Urbaniak-Zając, Piekarski 2001, p. 18), ethnographers (Denzin, Lincoln 1997, p. 17) may be recognized as pioneers of the method. The ethnographer's approach, as long as it is not only to observe and describe culture, but also to understand the intentions behind human actions, is to be typical of a qualitative researcher, who during the research becomes one with the world he studies together with the research subjects he constitutes the studied reality. To dwell upon this issue, I shall elaborate on the ways of researcher participation in exploratory research.

On all planes of the process of research (ontological, epistemological and methodological/methodical) there is a visible influence of biography, defined by the researcher's gender and his specific perspective of class, race, culture and ethnicity. The researcher, with multicultural perspective, approaches the world with a collection of ideas, a framework (theory, ontology), which determines the set of questions (epistemology) to be researched (methodology, analysis) in a particular way (Denzin, Lincoln 1997, p. 27). The elimination of reciprocal influence between the research subjects and the studied environment in the positivist paradigm was understood as a guarantee of objectivity of scientific study. In the interpretive paradigm, however, the relations between the researcher and research subjects have themselves become an important subject of study. In the relation "research subjectqualitative researcher" a certain dichotomy may be noticed. On the one hand, in qualitative research participant observation an attempt is made to prevent the researcher from disturbing the natural research environment (Malewski 1997). On the other, the researcher realizes that by getting in touch with the lives of research subjects he creates the reality in which they function, thereby influencing it. As I have mentioned before, the postmodernist paradigm allows for the deepest insight into the participation of a researcher in the research process. 
Supporters of the postmodernist approach claim that researcher's "self" may be constructed in various ways, and in various ways may it participate in scholarly discourse; therefore, each research is to be seen as the writing and rewriting of oneself and the world (Usher, Bryant, Johnston 2001, p. 7). It is hard to characterize the postmodernist paradigm precisely; that is why I do not perceive it as the fundament of research procedure, unlike the interpretive one. Nevertheless, the idea of researcher's "self" appears so interesting and well-grounded in the context of exploratory process that it may be included in the research.

Yet another author discussing researcher participation in the exploratory process is $\mathrm{N}$. Miller. The author claims that auto/biographical research may deal with the lives of others (e.g. students and teachers), become a reflection on one's own experience, personal history and identity, or, it may be a combination of both (Miller 2003, p. 121). The author emphasizes the importance of this type of research in andragogy; she proposes that in contemporary educational discourse the putting of emphasis on lifelong learning process rather than on adult education has influence on the identity of adult educators as well as on the context in which they function. Due to the aforementioned changes there is an increasing need for better understanding of the processes of learning how to study as well as for reflection on one's self and personal experience (Miller 2003, p. 124-125). N. Miller's text on auto/biographical research is rich in description of her own life experience and its influence on her scholarly work. The employing of the proposed ideas does not necessarily call for a researcher to describe his life story. However, it is my belief that one should address the experience that provided support for research procedure and the process of understanding the interpretation of gathered data. Reflection on the role of the researcher in research may help find an answer to the question: "how far have the subjective features of the researcher supported the research process, and how far have they disturbed it?".

\section{Autobiography, narrative, and identity}

The autobiographical, or auto/biographical-narrative research is an extremely interesting research procedure within the qualitative approach. The reference to personal experience in methodology A. Kłoskowska calls an individualizing reduction. Such observation of cultures at their roots is, according to the author, extremely effective in investigating the relations between national cultures and globalization (Kłoskowska 2002, p. 168). The persistence or impairment of national culture, the existence of international culture of universal, global or regional character or the lack thereof is realized at the roots - in 
individual human experience, identification and cultural assimilation (Kłoskowska 2002, p. 168).

A written history of one's life may be put to a manifold use. Biographies of famous people may be a source of inspiration and motivation to introduce changes in life. School students learn patriotism and other important values with the help of biographies of national heroes, poets and writers. Life narratives can doubtlessly serve as educational models. However, in the history of education there are numerous examples of fictional biographies being used for manipulation and political indoctrination ${ }^{5}$. Where lies, then, the power of biography? As we all know, autobiographies and memoirs are of great interest to readers. First of all, they allow for the following of biographical narratives of famous people, witnesses of important historical events, etc. Furthermore, biography seems to evoke interest due to its similarity to journalistic reports, rather than fiction. It describes the lives of real people, rather than fictional literary characters. Biography, being an account of an individual's life, is an image of social possibilities and barriers that have or have not been successfully used or overcome by an individual with the help of determination or coincidence (UrbaniakZając 2005, p. 118). One may, however, grow suspicious of biography's authenticity, since it is a collection of fragments of a lifelong history; some of the fragments may have been purposely omitted ${ }^{6}$ by the narrator, others described subjectively.

Therefore, questions arise: how far can scholars rely on personal history accounts of research subjects in interpreting them and coming to conclusions regarding phenomena of social life, behavior and national culture? When listening to narratives, do we witness real events, or just "made up" stories created to show the narrator in a positive light? Furthermore, if a researcher feels emotionally attached to the investigated problem he must take care not to allow the research to become an "autotherapy" and not to let personal experience dominate the interpreting of data. These are but a few problems that a researcher using the auto/biographical-narrative method may encounter.

I understand biography as a written life narrative. The telling/writing of a life narrative along with its accompanying reflection is a lifelong process. In research we present the trajectory of biography taking into account the past, the present, and one's attitude towards the future. We must bear in mind that research is an insight into biography from the

\footnotetext{
${ }^{5}$ One of the novels obligatorily read in soviet schools tells the story of Pavel Korchagin - a "hero" who sacrifices his family for communism and is ultimately killed.

${ }^{6}$ Narrator is to be understood both as an individual telling his own biography and as an individual telling the story of another person.
} 
perspective of the present. The perspective will change with each stage of one's life, enriched with new experiences and set in a new context. Like all qualitative research, biographical research is, therefore, characterized by unrepeatability of research findings.

If autobiography is considered a life narrative, identity in the methodological context is to be understood as a narrative of biography. The term "narrative" can be applied to the notion of identity in its two meanings: narrative as a human research subject's story of oneself and narrative as a metaphor of the process of the forming of identity. Let us hereby elaborate on the latter meaning.

D.P. MacAdams claims that identity is a life story (Pawlak 2000b, p. 131). There are more such metaphors in professional literature. Why is, then, the notion of narrative increasingly present in the context of the problem of identity? This question, in my opinion, allows one to perceive the changes that the understanding of human development has undergone.

The ideas of lifelong human development and permanent education demonstrate that with the reaching of psychophysical maturity one is not fully formed - on the contrary, one may still learn, achieve new goals, and be educated. It is proof that one develops into a person throughout all of one's life. According to K. Rosner, when characterizing the changes regarding the understanding of an individual in ontological terms it may be stated that structural being has been substituted with developing being, the existence of which begins with birth and ends in death (Rosner 2003, p. 18).

To address the above-mentioned issues, let us try to perceive the connection between the narrative and human identity.

A key characteristic of the narrative is its development in time - temporality (Rosner 2003, p. 19) - as well as its finitude (Rosner 2003, p. 19), for it has a beginning and an end. A conclusion may be drawn about structural similarities of identity and narrative that are manifested in such characteristics of identity as the temporal one - continuity in time - and biographical one - life stories. Regarding the continuity of identity, A. Giddens states that identity lies not in one's behaviour, nor in the outside perception. Identity lies in the ability to maintain the continuity of a certain narrative (Giddens 2002, p. 77), According to that author, an individual incorporates the events of the outside world into his life history to create a continuous story of himself (Giddens 2002, p. 77). Thus, identity appears to be a process of biographical acquisition of knowledge of oneself (Szlachcicowa 2003, p. 11). The character of 
thus constructed identity lets one understand oneself and one's actions from the perspective of a changing subject in a changing environment (Trzebiński 2001, p. 36-37).

The temporal character of identity is considered in two separate approaches, with their roots in two different paradigms - cognitive constructivism and social constructivism (Stemplewska-Żakowicz 2001, p. 82). The first model emphasizes the coherence and continuity of identity. It assumes that regardless of one's social role and situation one has the same identity. In this model, a lack of continuity, a feeling of "not being oneself" is considered an identity crisis (Banaszak-Karpińska 1998, p. 98). According to the second model, an individual embraces successive identities each time he enters a new relation network (Banaszak-Karpińska 1998, p. 98). Therefore, the first model emphasizes continuity and interprets identity on a mono dimension - as one constant life history, whereas the second one assumes a poli character of identity, thus displaying a preference for multiplicity of narratives.

I believe that despite fundamental differences the two models should be considered complementary. Both present the essence of identity in temporal perspective. The realization of one's own development in time is connected both with the sense of continuity of identity and a feeling of dislocation of the self. Time strengthens the sense of identity with, on the one hand, that which ensures its durability and stability, and on the other, that which fortifies the feeling of fortuity and infrequency; that which allows for the construction of histories of identity, as well as for their deconstruction (Kunce 2003, p. 110). The passage of time allows us to realize that we are no longer the same persons that we were ten years ago, or even a year ago. On the one hand, we still remain the same person, on the other, we perceive the world in a completely different way. We notice and describe the closing of chapters of our lives. That is why we may consider the ending of some of our life histories while still continuing the one unique history.

Regarding this issue, the notion of identity crisis leading to an interruption in the narrative needs to be considered. Senses of identity are temporal and it is only with the passage of time that they gain the status of a certain stable identity, just as with interruptions and discontinuity they become an unstable identity/non-identity (Kunce 2003, p. 109). If having overcome a crisis an individual returns to the former values, the crisis may be considered a climax of the narrative. If, however, one reconsiders his entire life and begins it anew, as it were, the crisis may be treated as an end of one narrative and a beginning of another. 
Let us now move on to discuss the biographical aspect of identity.

Biography is not only a sequence of events, but also a reflective interpretation of the events. D. Klus-Stańska states that reality is not reflected in the mind of an individual - it is constructed and repeatedly reconstructed (Klus-Stańska 2001, p. 191). Reflection accompanying the construction of biography - as proposed by W. Marotzki - is twofold. The first, diachronic one, is a process of a construction of meaning (Urbaniak-Zając 2005, p. 122). What constitutes an individual is that which one believes to be one's life, in the form of a life history. We picture our past and present time and again in the form of a history. Myself and the history that I consider my life are inseparable. Identity as a construct is a form of a history, presented as an individual's (self)narrative. The project of a human being has a structure of a narrative integration mechanism (Marotzki qtd in: Urbaniak-Zając 2005, p. 122-123). Yet another aspect of reflection in the construction of biography is the synchronic one, with its aim being the struggle for the acceptance of other people (Urbaniak-Zając 2005, p. 123). On the basis of the language of a narrative it may be stated that an individual as an author of a story constructs his own life history taking care to make the main character himself - appear in a positive light, to gain recognition of the readers. Such comparison is extremely interesting and not at all unjustified. Psychological research demonstrates that the recalling of autobiographical memories is influenced by the same factors that are decisive in the selection of information for public self-presentation (Tesser, Felson, Suls 2004, p. 201). The fact that subjective interpretations of one's life history may be constructed in order to be favourable to the appearance of the narrator does not necessarily imply that autobiographical narrative is completely false. It has been specifically emphasized by P. Lejeune, with the formulation of the so-called biographical pact and stating that autobiography has nothing to do with pure fiction (Lejeune 2001).

To conclude, identity in the narrative perspective is to be understood as a reflective construction of autobiography through the interpretation of one's actions, emotions and personal relations in the context of life events and the combining of those interpretations to form a single life history - a narrative of numerous plots. The fact that the forming of identity resembles a story justifies the use of narrative research methods.

A researcher who decides to use the discussed method of gathering data needs to be aware of its weak points. Biographical research using the narrative as a data source has often been criticised for the insufficiency of biographical material for the construction of statements and theory (Kłoskowska 2005, p. 117; Łobocki 2005, p. 310; Urbaniak-Zając 2005, p. 127). 
The criticism is serious and not altogether unjustified. It has already been mentioned that it is hard to generalise the results of qualitative research, which does not mean that they are of lesser value than the results of quantitative research. The aims of biographical methods and quantitative research are different. Biographies allow for the understanding of the meaning that individuals attach to their own actions in certain social and cultural contexts. Furthermore, despite the subjective character of data collected with the help of this method one notices certain regularities that allow for a better understanding of how people function in their world.

Further criticism is based on the subjective character of biographical data (Kłoskowska 2005, p. 117; Łobocki 2005, p. 310; Urbaniak-Zając 2005, p. 127). Subjectivity in the realm of qualitative research is to be understood as reaching beyond objective data, reaching towards interpretation, understanding and meaning (Zaręba 1998, p. 46). In this context subjectivity is undoubtedly an advantage, for how can one attach meaning to reality, if not subjectively? S. Palka claims that the phenomena related to values are often unique, variegated, and elusive to the thick tools of quantitative research (Palka 1989). Furthermore, one must bear in mind that despite their subjective character it is still the aim of qualitative research to seek objective scholarly knowledge. However, objectivism is pursued with methods different from those of the quantitative approach. The qualitative approach recognizes the independence of research subjects, avoids the imposing of terminology and negotiates the research results (Wyka 1990). However, to minimise the possibility of providing false information by the research subjects the researcher attempts to win the trust of the narrators. The autobiographical method has been criticised for supposedly allowing the research subjects to falsify and conceal information - the aforementioned method allows for a further refutation of those arguments (Lobocki 2005, p. 310).

The arguments against the biographical method are typical of the general criticism of qualitative research. Qualitative research relies on detail, which does not, however, imply a lack of original contribution. Unexpected details may not fit into the entire structure, which may need reconsideration. Having to incorporate a detail may require the changing of the structure in its entirety (Urbaniak-Zając 2005, p. 127).

\section{Bibliography:}


Ablewicz K. (1998), Hermeneutyka i fenomenologia $w$ badaniach pedagogicznych, [in:] Palka S. (ed.), Orientacje $w$ metodologii badań pedagogicznych, Wydawnictwo Uniwersytetu Jagiellońskiego, Kraków.

Banaszak-Karpińska E. (1998), Tożsamość jako kategoria badawcza, [in:] Szlachcicowa I. (ed.), Socjologia XXVI. Religia Przekonania Tożsamość, Wydawnictwo Uniwersytetu Wrocławskiego, Wrocław.

Benton T., Craib I. (2003), Filozofia nauk społecznych. Od pozytywizmu do postmodernizmu, DSWE, Wrocław.

Denzin N.K., Lincoln Y.S. (1997), Wkraczanie na pole badań jakościowych. Wprowadzenie do podręcznika, "Acta Universitas Nicolai Copernici. Nauki HumanostycznoSpołeczne. Socjologia Wychowania” 13(317).

Denzin N.K., Lincoln Y.S. (eds.) (1994), Handbook of Qualitative Research, Thousand Oaks, Sage Publications, London - New Delhi.

Gałdowa A. (ed.) (2000), Tożsamość Człowieka, Wydawnictwo Uniwersytetu Jagiellońskiego, Kraków.

Giddens A. (2002), Nowoczesność i Tożsamość, PWN, Warszawa.

Giza A. (1991), Życie jako opowieść. Analiza materiałów autobiograficznych w perspektywie socjologii wiedzy, PWN, Zakład Narodowy im. Ossolińskich, PAN, Wrocław Warszawa - Kraków.

Klus-Stańska D. (2001), Narracje w szkole, [in:] Trzebiński J. (ed.), Narracja jako sposób rozumienia świata, GWP, Gdańsk.

Kłoskowska A. (2005), Kultury narodowe u korzeni, PWN, Warszawa.

Kłoskowska A. (2002), Kultury narodowe wobec globalizacji, a tożsamość jednostki, "Kultura i Społeczeństwo" 2.

Koczanowicz L., Nahirny R.,Włodarczyk R. (eds.) (2005), Narracje-(Auto)biografia-Etyka, DSWE, Wrocław.

Kozakiewicz H. (1991), Zwierciadło społecznego świata, PWN, Warszawa.

Krasnodębski Z. (1986), Rozumienie ludzkiego zachowania. Rozważania o filozoficznych podstawach nauk humanistycznych i społecznych, PWN, Warszawa.

Kubinowski D., Nowak M. (eds.) (2006), Metodologia pedagogiki zorientowanej humanistycznie, Impuls, Kraków.

Kuhn T.S. (1968), Struktura rewolucji naukowych, PWN, Warszawa.

Kunce A. (2003), Tożsamość i postmodernizm, Elipsa, Warszawa. 
Lejeune F. (2001), Wariacje na temat pewnego paktu. O autobiografii, Lubas-Bartoszyńska

R. (ed.), Grajewski W., Jaworski S., Labuda A., Lubas - Bartoszyńska R. (trans.), Universitas, Kraków.

Łobocki M. (2005), Metody i techniki badań pedagogicznych, Impuls, Kraków.

Łobocki M. (1999), Wprowadzenie do metodologii badań pedagogicznych, Impuls, Kraków.

Malewski M. (1997), Metody ilościowe i jakościowe $w$ badaniach nad edukacją spór o metodologiczna komplementarność, "Kultura i Edukacja" 1-2.

Malewski M. (1998), Teorie andragogiczne. Metodologia teoretyczności dyscypliny naukowej, Wydawnictwo Uniwersytetu Wrocławskiego, Wrocław.

Miller N. (2003), Auto/biografia w badaniach nad edukacją i uczeniem się całożyciowym, “Teraźniejszość - Człowiek - Edukacja” 1(21).

Nikitorowicz J. (2001), Pogranicze, Tożsamość, Edukacja międzykulturowa, Trans Humana, Białystok.

Nowak-Dziemianowicz M. (2006), Doświadczenia rodzinne w narracjach, DSWE, Wrocław.

Palka S. (1989), Ilościowo-jakościowe badania pedagogiczne, "Ruch Pedagogiczny” 1.

Palka S. (ed.) (1998), Orientacje $w$ metodologii badań pedagogicznych, Wydawnictwo Uniwersytetu Jagiellońskiego, Kraków.

Pawlak J. (2000a), Odraczanie decyzji o tożsamości: problemy z dojrzałościa emocjonalna jako przyczyna przedtużania moratorium, [in:] Gałdowa A. (ed.), Tożsamość Człowieka, Wydawnictwo Uniwersytetu Jagiellońskiego, Kraków.

Pawlak J. (2000b), Paula Ricoeura koncepcja tożsamości narracyjnej., [in:] Gałdowa A. (ed.), Tożsamość Człowieka, Wydawnictwo Uniwersytetu Jagiellońskiego, Kraków.

Pryszmont M. (2004), Eklektyzm metodologiczny, czyli interparadygmatyczne przygody badawcze, “Teraźniejszość - Człowiek - Edukacja” 1 (25).

Rosner K. (2003), Pojęcie narracji a proces formowania się tożsamości, "Kultura i Społeczeństwo" 3.

Smith L.M. (1994), Biographical Method, [in:] Denzin N.K., Lincoln Y.S. (eds.), Handbook of Qualitative Research, Thousand Oaks, Sage Publications, London - New Delhi.

Stemplewska-Żakowicz K. (2001), Koncepcje narracyjnej tożsamości. Od historii życia do dialogowego "ja”, [in:] Trzebiński J. (ed.), Narracja jako sposób rozumienia świata, GWP, Gdańsk.

Sujak E. (1998), Rozważania o ludzkim rozwoju, Znak, Kraków. 
Szlachcicowa I. (2003), Trwanie $i$ zmiana: międzygeneracyjne różnice $w$ strategiach opracowywania zmiany społecznej, [in:] Szlachcicowa I. (ed.), Biografia a tożsamość, Wydawnictwo Uniwersytetu Wrocławskiego, Wrocław.

Szlachcicowa I. (ed.) (1998), Socjologia XXVI. Religia Przekonania Tożsamość, Wydawnictwo Uniwersytetu Wrocławskiego, Wrocław.

Szlachcicowa I. (ed.) (2003), Biografia a tożsamość, Wydawnictwo Uniwersytetu Wrocławskiego, Wrocław.

Tesser A., Felson R.B., Suls J.M. (eds.) (2004), Ja i tożsamość perspektywa psychologiczna, GWP, Gdańsk.

Trzebiński J. (2001), Narracyjne konstruowanie rzeczywistości, [in:] Trzebiński J. (ed.), Narracja jako sposób rozumienia świata, GWP, Gdańsk.

Trzebiński J. (ed.) (2001), Narracja jako sposób rozumienia świata, GWP, Gdańsk.

Urbaniak-Zając D. (2006), W poszukiwaniu kryteriów oceny badań jakościowych, [in:] Kubinowski D., Nowak M. (eds.), Metodologia pedagogiki zorientowanej humanistycznie, Impuls, Kraków.

Urbaniak-Zając D. (2001), J. Piekarski, Badania jakościowe, uwagi wprowadzajace, [in:] Urbaniak-Zając D., Piekarski J. (eds.), Jakościowe orientacje w badaniach pedagogicznych, Wydawnictwo UŁ, Łódź.

Urbaniak-Zając D., Piekarski J. (eds.) (2001), Jakościowe orientacje $w$ badaniach pedagogicznych, Wydawnictwo UŁ, Łódź.

Urbaniak-Zając D. (2005), Pedagogiczna perspektywa $w$ badaniach narracyjnobiograficznych, [in:] Koczanowicz L., Nahirny R., Włodarczyk R. (eds.), Narracje(Auto)biografia-Etyka, DSWE, Wrocław.

Usher R, Bryant J., Johnston R. (2001), Podmiot poznajacy $w$ badaniach edukacyjnych (perspektywa postmodernistyczna), "Teraźniejszość - Człowiek - Edukacja” 2 (14).

Wyka A. (1993), Badacz społeczny wobec doświadczenia, IFiS PAN, Warszawa.

Wyka A. (1990), Ku nowym wzorom badań społecznych w Polsce, cechy badań jakościowych w ostatnich latach, "Kultura i Społeczeństwo" 1.

Zaręba E (1998), Badania ilościowe i jakościowe w pedagogice, [in:] Palka S. (ed.), Orientacje $w$ metodologii badań pedagogicznych, Wydawnictwo Uniwersytetu Jagiellońskiego, Kraków. 